\title{
Behaviour and Daily Activity Rhythm of European Bison in Winter
}

\author{
Krystyna CABOŃ-RACZYŃSKA, Małgorzata KRASIŃSKA \& \\ Zbigniew KRASIŃSKI
}

\begin{abstract}
Caboń-Raczyńska K., Krasińska M. \& Krasiński Z. A., 1983: Behaviour and daily activity rhythm of European bison in winter. Acta theriol., 28, 18: 273-299 [With 3 Tables \& 8 Figs.]

A description is given of the basic patterns of behaviour in the European bison, Bison bonasus Linnaeus, 1758, during the winter in the Bialowieża Primeval Forest such as: feeding, drinking, eliminative behaviour, resting (lying and standing), grooming, walking, playing, sexual behaviour and cow-calf relationships. It was found that there is considerable similarity to the characteristics of behaviour in the American bison. In turn analysis was made of the daytime and daily activity rhythms, based on 94 observations of the whole herd and of different individuals from different age-sex classes. The activity rhythm of European bison was found to consist of many phases, feeding phases being interspersed with rest. European bison spend $60 \%$ of the 24-hour period in resting, $30 \%$ in feeding and $10 \%$ in walking. In winter their activity is low, and is chiefly connected with one walk during the day in the afternoon hours to a drinking place. Extreme temperatures were observed to contribute to a shift in time of activity phases. The phases of behaviour of different individuals was not found to be in complete coincidence in time, the most strongly synchronized being rest (lying) and walking to the drinking place, whereas some part of the herd feeds throughout the whole 24-hour period. The observations made led to conclusions as to principles for selection, forms of supplementary feeding and localization of feeding places.
\end{abstract}

[Mammals Res. Inst., 17-230 Białowieża (KCR, MK) and Białowieża National Park, 17-230 Białowieża (ZAK), Poland]

\section{INTRODUCTIONS}

The natural population of European bison in the Białowieża Primeval Forest persisted up to the beginning of the 20th century. There is a considerable amount of information on the behaviour and habits of these large ruminants to be found in papers published during this period dealing with the Białowieża Primeval Forest (Karcov, 1903) or solely with European bison (Wróblewski, 1927). Although such data are fragmentary and incomplete, they constitute valuable material for the studies now being carried out.

The restitution of the free-ranging European bison population in the Białowieża Primeval Forest after World War II began in 1952. In 1971 
the population consisted of more than 200 animals and during the subsequent 10 years numbers were controlled and maintained on a level of 210-250 animals (Krasiński, 1967, 1978).

Studies on the behaviour and activity rhythm of these bison at different season of the year form part of studies aimed at determining the ecology of this species (Pucek, 1967). The present study relates to the winter period, during which the natural activity rhythm undergoes considerable changes as the result of supplementary feeding, almost entirely satisfying the food requirements of these animals. In consequence the winter wanderings in search of natural food are limited to a minimum, and locomotor activity also undergoes considerable limitation. The concentration of bison round feeding places and their relative lack of timidity during this period create opportunities for longer and detailed observation. Daily activity rhythm and certain characteristics of their behaviour, specific to the species, may differ from the pattern occurring in animals not provided with supplementary food in winter.

In recent times daily activity rhythm was examined in European bison kept in small enclosures in Prague Zoo (Vajner, 1980) and in enclosures of the "Amsterdamse Bos" reserve (Van Den Brink, 1980). In the eastern part of the Białowieża Primeval Forest Koročkina (1972) described the activity of these animals in summer.

The purpose of this study was to describe behaviour in winter and to determine the activity patterns of European bison, Bison bonasus Linnaeus, 1758, in the Białowieża Primeval Forest and to estimate the effect of factors connected with breeding care, and in particular, ways of supplementarily feeding European bison on their behaviour and activity.

\section{MATERIAL AND METHODS}

A mixed naturally formed group of European bison round winter feeding places (sector 422) was regularly observed during the winter (December-March) over the period from 1976 to 1981 . The herd consisted of $55-60$ individuals, $12 \%$ of which were adult bulls $>4$ years old, $40 \%$ adult cows $>4$ years, $30 \%$ iuveniles from $2-3$ years old and $18 \%$ calves. There were certain variations in the composition of the herd in different study years, chiefly in respect of the proportion of bulls, which during the winter period often changed the place in which they lived. Cows and juveniles return every year to the same feeding place and remain there throughout the entire winter, as was shown by observations of marked individuals.

The bison are supplementarily fed with hay in winter, and from time to time with fodder beet. As from July hay is kept in stacks, but the bison do not 
begin to make regular use of hay until after 15 th November when the first snow falls. At the beginning of winter the animals eat direct from haystacks, and from January-February, when the stacked hay has nearly come to an end, it is daily taken to the place in which the herd is spending the winter and laid out in smal portions on the snow on distance of $100-150 \mathrm{~m}$. The hay is transported there at a constant time between 10.00-12.00.

The behaviour of the bison was directly observed over a period of $2-3$ hours at different times of the day, making a total of 635 observations. Examination was made of feeding, drinking, eliminative behaviour, playing, grooming, walking, resting (standing and lying), sexual behaviour, aggressive behaviour and calf-cow relationships. The time of feeding calves was measured, determining the age and condition of calves. A record was also kept of interspecific reactions and of Furopean bison and man reaction, using the terminology employed by Shult (1972) for the American bison.

A total of 94 observations was also made of the activity rhythm of European bison, including 9 24-hour and 17 daytime periods of the herd's activity and 68 observations of the daytime activity of different individuals from all sex and age classes. Daily activity rhythm was studied by carrying out continuous observations directly from dawn to dusk (average observations time 9 hours) (Table 1).

Daily activity in the herd was examined for 24 hours when the moon was full. Daytime activity was determined for the whole herd and also for single individuals, using $7 \times 150$ field glasses from a distance of 30-50 metres, and at night using $15 \times 50$ field glasses. The daytime activity rhythm of different individuals was continuously observed, recording each change of behaviour. The activity rhythm of the whole winter group was recorded during the daytime every 15 minutes, and at night every 30 minutes, counting the number of animals in the given phase of activity. Distinction was made between the time taken for feeding on hay or natural foods (bark, shoots). For the locomotor activity phase distinction was made between actual movement (walking), playing, grooming and sexual behaviour. Lying and standing was defined as resting, making a distinction between the time used for ruminating during these two phases of behaviour. The activity rhythm of the animals was discussed separately, ciepending on the two types of feeding, on hay from stacks and hay laid out in numerous portions on snow.

Using the data obtained, diagrams were drawn up of the daily activity of the herd and the average daytime activity of a given age-sex group, by calculating the percentage of individuals in the herd engaged in the given activity and, at the same time, the percentage of time spent in different activities in each qurter or half hour. Significance of differences was checked by the Student $t$ test.

Examination was also made of the effect of temperature on the daily activity rhythm of European bison. During the observation period this varied from $+4^{\circ} \mathrm{C}$ to $-19^{\circ} \mathrm{C}$. 
Table 1

Average time of daytime activity of European bison ( \pm SD) in hours.

\begin{tabular}{|c|c|c|c|c|c|c|c|c|}
\hline Activity & $F, a^{1}$ & $F, \mathrm{ad}^{2}$ & $\mathrm{M}, \mathrm{ad}^{1}$ & $\mathrm{M}, \mathrm{ad}^{2}$ & M, 2-3 yrs. F, & $2-3$ yrs. & Calves ${ }^{1}$ & Calves $^{2}$ \\
\hline Standing and laying & $2.9 \pm 1.0$ & $3.2 \pm 1.2$ & $2.9 \pm 1.9$ & $3.3 \pm 1.4$ & $3.8 \pm 1.1$ & $4.0 \pm 1.2$ & $3.5 \pm 1.0$ & $3.2 \pm 1.1$ \\
\hline Rumination & $1.8 \pm 1.0$ & $1.6 \pm 0.6$ & $1.0 \pm 0.9$ & $0.9 \pm 0.7$ & $2.2 \pm 1.3$ & $2.1 \pm 0.6$ & - & - \\
\hline Feeding & $3.0 \pm 1.0$ & $3.7 \pm 1.2$ & $1.8 \pm 1.3$ & $3.0 \pm 0.5$ & $3.0 \pm 0.9$ & $2.7 \pm 1.0$ & $1.7 \pm 0.8$ & $3.6 \pm 1.2$ \\
\hline Walking & $1.7 \pm 1.1$ & $1.5 \pm 0.8$ & $1.2 \pm 1.4$ & $1.4 \pm 0.7$ & $1.4 \pm 1.2$ & $2.3 \pm 0.9$ & $1.6 \pm 1.2$ & $1.7 \pm 1.2$ \\
\hline Sexual behaviour & $\bar{x}$ & $\mathbf{x}$ & $2.5 \pm 2.3$ & $1,3 \pm 2.2$ & $0.1 \pm 0.2$ & 一 & - & 一 \\
\hline Playing & - & - & - & - & $0.4 \pm 0.3$ & $\mathbf{x}$ & $\mathbf{x}$ & $\mathrm{x}$ \\
\hline Aggresive behaviour & $\mathbf{x}$ & $x$ & - & - & $\mathrm{x}$ & 一 & $1-\overline{1}$ & $-1 \div 0$ \\
\hline Mother-calf relationship & $0.2 \pm 0.2$ & $0.1 \pm 0.1$ & - & - & - & $\overline{10}$ & $0.2 \pm 0.2$ & $0.2 \div 01$ \\
\hline Eliminative behaviour & $0.1 \pm 0.1$ & $0.1 \pm 0.1$ & 3 times & $0.1 \pm 0.1$ & $0.1 \pm 0.1$ & $0.1 \pm 0.1$ & - & - \\
\hline Grooming & $0.3 \pm 0.3$ & $0.1 \pm 0.1$ & $0.2 \pm 0.3$ & $0.2 \pm 0.2$ & $0.4 \pm 0.3$ & $0.3 \pm 0.2$ & $0.2 \pm 0.2$ & 一 \\
\hline Eating snow & $0.1 \pm 0.1$ & $0.1 \pm 0.1$ & 一 & $0.7 \pm 0.1$ & $0.3 \pm 0.2$ & $0.3 \pm 0.2$ & 一 & 一 \\
\hline $\begin{array}{l}\text { Combined time of } \\
\text { daytime observations }\end{array}$ & $8.6 \pm 0.6$ & $9.0 \pm 0.6$ & $8.6 \pm 0.6$ & $9.4 \pm 1.0$ & $9.5 \pm 1.4$ & $9.7 \pm 1.1$ & $7.2 \pm 1.7$ & $8.7 \pm 1.1$ \\
\hline
\end{tabular}

Explanations: $x$ - only a few cases observed among the animals; 1 - during period when hay is stored in stacks; 2 - during period when hay is laid out in small portions on the snow daily. 


\section{BEHAVIOUR}

\subsection{Feeding}

The basic food of European bison in winter is good quality hay, which is stored in roofed stacks in places of winter concentration, and thus the bison are able to make use of it at any time and in unlimited amounts. As from mid-January, when hay in stacks has been consumed, a supply is taken to the feeding places at the same time each day. The bison wait for the arrival of the hay, reacting to the familiar sound of sledges or tractor by approaching in its direction. Usually cows and bulls are the first to approach, and the juveniles and calves follow them. When fodder beet is laid out domination and hierarchy appear even more distinctly. Cows at the top of the hierarchical ladder and adult bulls are the first to approach the beet and drive away other animals. After they have finished feeding the bison lie down or ruminate standing up $(62 \%)$, and less often lie or stand without ruminating ( $32 \%$ of observations).

European bison was barking different trees such as: ash, hornbeam, various species of willow, spruce, lime and alder within a radius of several hundred metres from the feeding place. The greatest number of barked trees are encountered on the route to the drinking place. If tree-felling is being carried out in the vicinity the animals visit these places, stripping the bark from the felled trees, preferably aspen. They only irregularly make use of the salt blocks laid out.

\subsection{Drinking}

European bison quench thirst by drinking water or eating snow. Almost $80 \%$ of the herd goes daily to drink water. An alder forest situated at a distance of $200-300 \mathrm{~m}$ from the feeding places serves them as a drinking place. Every day between 12.00 and 14.00 one or more adult cows set off to the drinking place along the path trodden in the snow. Other animals in turn get up and go to the forest one after the other at a distance of $20 \mathrm{~m}$ from each other. Within the alder forest the bison scatter, trampling the snow or throwing it aside with the muzzle, and drink water for several minutes from the hollows formed in this way. They tread down hollows in a new place every day, as the water freezes in the ones made previously. They also return gradually. Frequently it is the juvenile animals and calves which return first ( $40 \%$ of observations). Young animals were observed several times to return at a run (25\% of observations). Once two 3 -year old males rolled on the ground after such a run, pawed the snow with their hoofs and struck the feathery snow over with their horns. Drinking 
water uras observed less often, after the animals had first broken ice on a strearn flowing near the place of winter supplementary feeding, or from puddles during thaws (16\% of observations). Eating snow is another way of obtaining water in winter, and is observed from 1-4 times a day in all European bison (Table 2).

\subsection{Eliminative Behaviour}

During winter elimination is observed $1-2$ daily in European bison (Table 2). During defecation the bison always adopt a squatting position. Cows may urinate while moving, but this is very seldom observed. Elimination is most often observed when the bison get up after resting

Table 2

Frequency of activity units during day

\begin{tabular}{|c|c|c|c|c|c|c|c|c|c|c|c|c|c|}
\hline $\begin{array}{l}\text { Group of } \\
\text { animals }\end{array}$ & 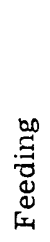 & 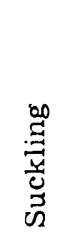 & 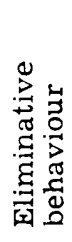 & 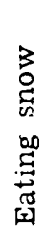 & 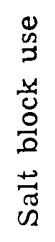 & 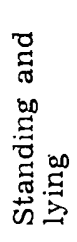 & $\begin{array}{l}\stackrel{\infty}{\Xi} \\
\stackrel{\Xi}{*} \\
3 \\
3\end{array}$ & 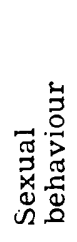 & 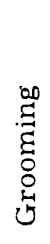 & 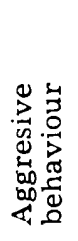 & 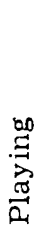 & $\frac{2}{\stackrel{\Xi}{\Xi}}$ & 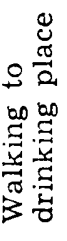 \\
\hline Females $a d^{1}$ & 3 & - & 2 & 1 & I & 5 & 2 & 0 & 2 & 0 & 0 & 1 & 1 \\
\hline Females $a^{2}$ & 4 & - & 1 & 1 & I & 5 & $\overline{2}$ & 0 & 1 & 0 & 0 & - & 1 \\
\hline Males ad ${ }^{1}$ & 3 & - & 1 & 一 & 1 & 4 & 3 & $S$ & 1 & - & 0 & - & 1 \\
\hline Males $\mathrm{ad}^{2}$ & 3 & - & 1 & 1 & $\mathrm{I}$ & 4 & 2 & $S$ & 1 & - & 0 & - & 1 \\
\hline Males $2-3$ yrs. & 4 & - & 1 & 4 & 1 & 4 & 3 & 1 & 2 & 0 & 2 & 1 & 1 \\
\hline Females $2-3$ yrs. & 3 & - & 1 & 2 & I & 5 & 3 & - & 3 & 一 & 1 & + & 1 \\
\hline Calves ${ }^{1}$ & 3 & $1-3$ & - & I & 一 & 6 & 2 & 一 & 1 & - & I & - & 1 \\
\hline Calves ${ }^{2}$ & 3 & $1-2$ & - & I & - & 5 & 2 & - & 1 & - & I & - & 1 \\
\hline
\end{tabular}

Abbreviations: I - irregular; 0 - occasional; S - several times; + - one case. Explanations see Table 1 .

( $44 \%$ of observations) or cease eating ( $35 \%$ of observations). Increased emotional tension caused by disturbance usually evokes a reaction in the form of deiecation or urination.

\subsection{Cow-calf Relationships}

The cow-calf relationships observed in winter consist only in feeding and sporadic care in the form of licking the calf before or during suckling. By winter calves have reached an age when they no longer spend the whole day in the immediate vicinity of their mothers, and are no longer actively defended by the cow from other members of the herd, as is the case during the first months of their life. In mixed winter groups the majority of the calves were born early (May-July), 
although there were some cases of calves born late (Aug.--Oct.). Some of these calves, particularly those born in October, developed more weakly and entered upon the winter period in poor condition. Several cases were observed of such calves being deserted by their mothers.

The time of feeding calves from the first group was longer and more regular, being on an average $8.3 \pm 4.6$ minutes than for the second group for which the time was $6.6 \pm 5.3$ (Table 3). A statistically significant difference was recorded between the length of suckling time of calves born early in December and January - $0.02<P<0.05$. In December the calves born early suckled for a significantly $(P<0.05)$ longer time than those born late. In winter the time during which calves of the two groups sucked varied from 3-26.5 minutes. The calves sucked $1-3$ times at different times of the day (Table 3 ). Usually calves which sucked for longer than 10 minutes sucked only once daily. During nocturnal observations calves were seen sucking during the time the cows fed, but it was impossible to determine for how long.

The signal for the start of suckling is the cow's grunting $(50 \%$ of observations), to which the calves react by running rapidly to the cow and beginning to suck. A signal of this kind may be given first by the calf $(50 \%$ of observations) and the cow then responds if it wishes to give suck. In $70 \%$ of observations the calf sucked its mother while standing at its side. If sucking continued longer the calf changed its position and sucked from behind the cow. If the cow was moving or tried to get away from the calf, which wanted to continue sucking, or bad begun to do so, it ran in front of the cow, although the latter did not always stop. When the cow is lying down the calf sometimes approaches it and butts its body with its head several times, until the cow rises and begins to suckle the calf ( $4 \%$ of observations). The cow usually ruminates while the calf is sucking. It was rarely observed that the cow licked different parts of the calf's body before giving suck, although such grooming was observed several times during feeding. Several times one cow was observed to suckle two calves. A 2-year old individual was observed additionally to suck five times, and calves from the same year six times from other cows (out of 108 observations). A case was observed once only of a late-born calf sucking a cow not its own mother for 15 minutes (Table 3).

\subsection{Resting - Standing or Lying}

European bison rest either standing or lying. When starting to lie down they kneel on the carpus, draw their rear legs up under them, lower the front of the body and then the rear. They most often lie on 
the sternum, less often on the side, when they then have the head supported on the ground and legs stretched out. In getting up they change to kneeling position, then quickly raise the front, then the back of the body. When standing up they shake themselves, and calves bend the back downwards, raising the tail. They often lie down on hay round the covered stack or lying on the snow. While standing or lying they ruminate for a long time. Sleep with closed eyes is rarely observed during the day, and then only in adult cows and juvenile animals (Table 2). Sleep lasts 5-20 minutes.

Table 3

Time European bison calves suck during winter period.

\begin{tabular}{|c|c|c|c|c|c|c|c|c|c|c|}
\hline \multirow{2}{*}{$\begin{array}{l}\text { Group } \\
\text { of } \\
\text { calves }\end{array}$} & \multirow[b]{2}{*}{$\begin{array}{l}\text { Age, } \\
\text { months }\end{array}$} & \multirow{2}{*}{ Period } & \multicolumn{4}{|c|}{ Sucking time, min. } & \multicolumn{3}{|c|}{$\begin{array}{c}\text { Frequency of } \\
\text { sucking } \\
\text { periods } \\
\end{array}$} & \multirow{2}{*}{$\begin{array}{l}\text { Feeding alien } \\
\text { calves }\end{array}$} \\
\hline & & & $\min$. & $\max$. & $\overline{\mathbf{x}}$ & $\mathrm{N}$ & $5^{\prime}$ & $6-9^{\prime}$ & $10^{\prime}$ & \\
\hline & $\begin{array}{l}5-7 \\
6-8\end{array}$ & $\begin{array}{l}\text { Dec. } \\
\text { Jan. }\end{array}$ & $\begin{array}{l}4.0 \\
3.3\end{array}$ & $\begin{array}{l}24 \\
15\end{array}$ & $\begin{array}{r}10.2 \pm 5.3 \\
6.6 \pm 2.7\end{array}$ & $\begin{array}{l}26 \\
22\end{array}$ & $\begin{array}{l}23.1 \\
36.4\end{array}$ & $\begin{array}{l}34.6 \\
50.0\end{array}$ & $\begin{array}{l}42.3 \\
13.6\end{array}$ & $\begin{array}{l}1 \text { time } 2 \text { year old } \\
2 \text { time of same age }\end{array}$ \\
\hline I & $7-9$ & Feb. & 3.5 & 15 & $7.6 \pm 3.6$ & 15 & 20.0 & 40.0 & 40.0 & $\begin{array}{l}2 \text { time } 2 \text { year old } \\
2 \text { time of same yr. }\end{array}$ \\
\hline \multirow[t]{2}{*}{ Total } & $\begin{array}{l}8-10 \\
5-10\end{array}$ & $\begin{array}{l}\text { March } \\
\text { Dec.- }\end{array}$ & 3.6 & 20.3 & $7.4 \pm 5.3$ & 7 & 28.2 & 57.1 & 14.3 & $\begin{array}{l}1 \text { time } 2 \text { year old } \\
1 \text { time of same age }\end{array}$ \\
\hline & & March & 3.3 & 24 & $8.3 \pm 4.6$ & 70 & 27.1 & 42.9 & 30.0 & $\begin{array}{l}4 \text { time } 2 \text { year old } \\
5 \text { time of same yr. }\end{array}$ \\
\hline \multirow{3}{*}{ II } & $2-4$ & Dec. & 4.0 & 26.5 & $8.0 \pm 6.2$ & 18 & 55.5 & 22.2 & 22.3 & \multirow{5}{*}{$\begin{array}{l}1 \text { time } 2 \text { year old } \\
1 \text { time of same age } \\
1 \text { time alien } \\
\text { mother }\end{array}$} \\
\hline & $3-5$ & Jan. & 3.0 & 15 & $5.8 \pm 4.3$ & 11 & 54.5 & 36.4 & 9.1 & \\
\hline & $4-6$ & Feb. & 3.0 & 15 & $5.3 \pm 3.8$ & 8 & 75.0 & 12.5 & 12.5 & \\
\hline \multirow{2}{*}{ Total } & 5-7 & March & & & 3.4 & 1 & & & & \\
\hline & & March & 3.0 & 26.5 & $6.6 \pm 5.3$ & 38 & 60.5 & 23.7 & 15.8 & \\
\hline
\end{tabular}

Explanations: Group I - early spring - Calves born during May-July period; Group II - late summer, autumn - calves born during August-October period.

\subsection{Grooming}

This type of activity includes rubbing, licking the coat, tail switching and wallowing. This type of behaviour is observed in all the bison regardless of sex and age.

For rubbing the bison use the fencing of hay stacks, broken or felled tree trunks, fallen spruce, and the trunks of standing trees. They rub different parts of the body. The underbelly region is rubbed by straddling a lying tree trunk and rubbing front and back by rhythmic movements parallel to the body axis. In order to rub the back the bison position themselves under a sloping tree and squatting slightly 
rub with a rhythmic movement. They have been observed to break young spruce and then rub the whole body on the broken branches.

Wallowing in winter is rarely observed in calves ( $8 \%$ of observations), more often in juvenile animals $\left(16.4^{\%} \%\right.$ ), but is a constant element of the behaviour of adult animals $(75.6 \%)$. The European bison sometimes begin to wallow while lying, if there is a raised bit of ground near them $\left(26^{0} \%\right.$ of observations). They wallow by raising all four legs upwards several times, get up, shake themselves, then wallow on the cther side, after which they again rise and begin to rub themselves. Near the winter feeding place the bison use the slightly rising ground in the forest, and heaps of sand intended for scattering on roads, for wallowing. When a bison approaches the place in which it intends to wallow, it removes the snow with its front legs and then wallows. On one day 8 bison in turn were observed to go to the same hillock and wallow.

Bison also frequently lick their coat, when either lying down or standing. They lick all the places which they can reach. They were also frequently observed to scratch the front parts of the body with a hind leg.

Tail switching is rarely observed in winter. Such behaviour as a part of grooming takes place very frequently in summer, particularly when there is considerable invasion by insects. It is also observed in calves as an element of their behaviour while sucking, and in adult bulls as part of their sexual behaviour while frightening off a rival.

\subsection{Sexual Behaviour}

This type of behaviour is observed in European bison during the mating season (August-October) (Krasiński \& Raczyński, 1967) and certain of its elements occur in winter also. Young 2-4 year old bulls, which form part of the mixed group, walk among cows and heifers, smell their genital regions and then adopt the lip curl posture. This is sometimes accompanied by an attempt at mounting to which the cow reacts by moving away. If there is an adult bull (which is not usually the case) in the winter group, it walks about among the cows, smells several in turn, smells urine and several times adopts the lip curl posture.

During winter observations oestrus was observed eight times, with the typical manifestations such as described for European bison in summer (Krasiński \& Raczyński, 1967). Oestrus was observed once in December, six times in January and once in February. All the cows had calves several months old, one of the cows (a marked one) exhibiting oestrus symptoms in three successive winter months, without becoming 
pregnant. The cow with oestrus symptoms remained on the fringe of the herd and was accompanied by an adult bull forming the tending bond. The bull smelt and licked the genital regions of the cow, and when the latter attempted to approach the herd the bull ran in front of it forcing it to stop. The bull several times during the day mounted the cow and the cow also mounted the bull. When a calf approached the cow to suck it the bull drove it away, as did the cow several times. In the intervals between mounting the cow the bull licked it on the head, neck, sides and frequently adopted the lip curl posture. Sometimes before mounting the cow the bull rested its chin on the cow's lumbar region. Young bulls $4-5$ years old attended the pair at a slight distance. They sometimes pushed each other about or rubbed against trees. If they approached too close to the cow they were frightended oif by the accepted bull lowering its head, switching its tail, shaking its head several times and moving towards the intruder. The young bull always retreated. At least once during the day the bull interrupted its attentions, moved a few steps away from the cow, pawed the snow with its front legs, wallowed on both sides of the body, rose, shook itself and again returned to the cow. During the time the bull attended the cow it ate no hay at all, although the cow ate from time to time.

\subsection{Playing}

This type of behaviour is only sporadically observed among adult animals in winter (Table 2). Young cows, or a young cow with a young bull, were only occasionally observed to butt each other, but this was more often observed among juveniles and calves of both sexes. During the warmer part of the day between 10.00 and 15.00, when the locomotor activity of European bison increases, juveniles and calves were observed to play. Calves play irregularly during the day, butt each other, and run and caper. Calves often try to mount each dther. Young 2-4 year old bulls butt each other with their horns - from two to three animals over periods of 5-10 minutes. Heifers and young bulls also butt each other and young bulls were observed mounting heifers. During return from the drinking place juveniles and calves run and butt each other.

\subsection{Interspecies Reactions}

During winter European bison come into contact with wild boar and roe deer, and once a lynx's traces were seen near the place where European bison were accustomed to stand. A herd of wild boar was observed thirteen times rooting near European bison, and they also 
slept at night on the hay round haystacks. Wild boar were seen to pass between recumbent bison, although no reaction was seen on the part of the latter. A 18-month old bull was once seen to drive away a young wild boar. Herds of red deer feeding at a distance of $20-30 \mathrm{~m}$ from European bison were observed twelve times near the winter supplementary feeding site. A group of does was only once observed to pass between recumbent bison, which exhibited no reaction. It can thus be seen that wild boar and red deer from time to time make use of the winter feeding place without appearing to arouse any antagonism.

\subsection{Reaction to Man}

During the period of several years' winter observations European bison were only rarely observed to exhibit aggressive behaviour to man (attack). In winter during the day they react completely differently to seeing humans than they do in summer, as most probably they connect humans with supplies of fodder. If a human being moves quietly and does not approach them too closely, they break off feeding for a moment and watch, but within a few minutes return to their interrupted feeding. The presence of an observer is similarly accepted with indifference and does not affect their behaviour, as long as the observed behaves circumspectly. It is rarely that European bison react to seeing humans by running away, as Krasinski (1978) observed earlier on. This is, however, a frequent reaction in summer. The impulse to escape spreads through the herd usually by imitation and is observed in bison not having daily contact with man. It is the young animals which most rapidly take fright and they are the first to run away. A sudden sound of snapping, e.g. a broken branch, is the most frequent stimulus to flight. European bison are more vigilant at night than during the day. They react strongly to light and the movement of windscreen wipers. They are not disturbed by a walking observer, to whose presence they quickly accustom themselves. If, however, the herd takes fright it comes to a halt after running several metres. After a certain time it gradually returns to the feeding places. Old cows very rarely run away with other members of the group.

\section{ACTIVITY RHYTHM}

\subsection{Daytime Activity}

Feeding occupies from $21-41 \%$ of the European bison's period of daytime activity (Fig. 1). It lasts significantly longer in both adult cows and bulls $(0.02<P<0.05)$, and is highly significantly longer in calves 
$(P<0.001)$, when hay is laid out over a larger area. This fact can be explained by the absence of competition between individuals, since food is then uniformly accessible to the whole herd. When hay is available only in stacks, the stronger adult individuals are the first to feed, and the young animals are able to feed only after the older animals have moved away. Calves are only able, for all practical purposes, to feed on hay scattered round the stacks.

Resting - standing or lying, even combined with ruminating, occupies
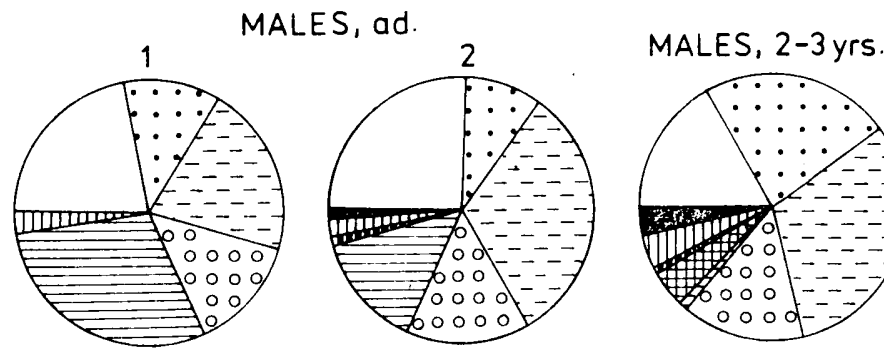

FEMALES, 2-3 yrs.
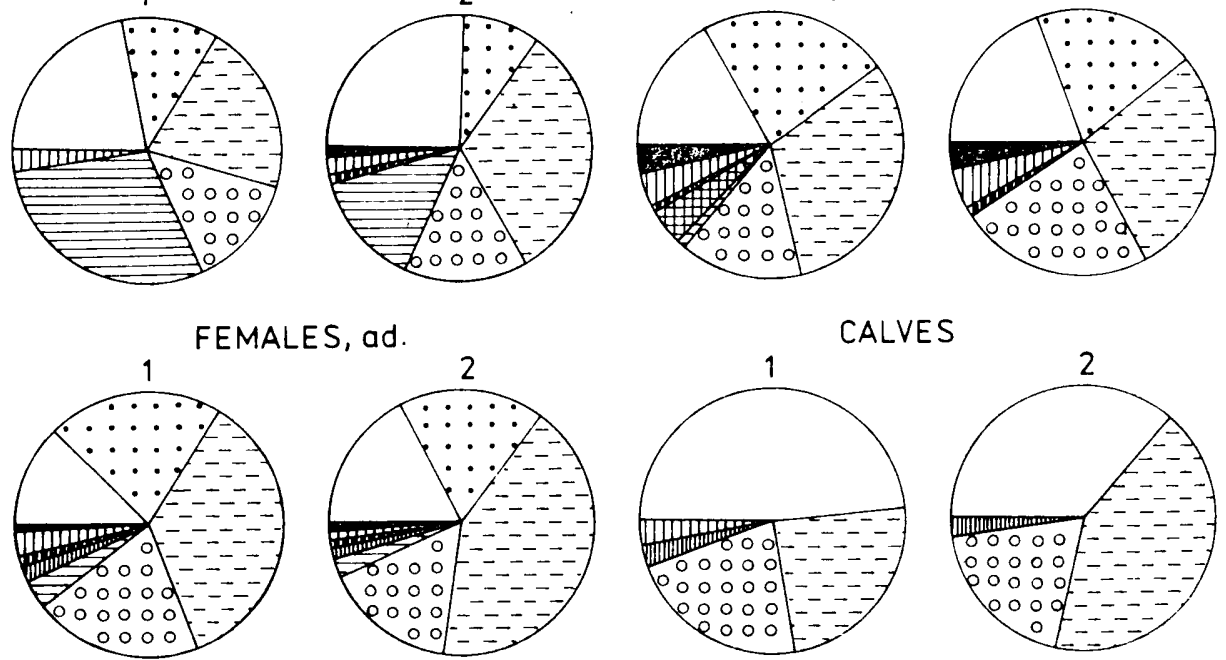

\section{CALVES}
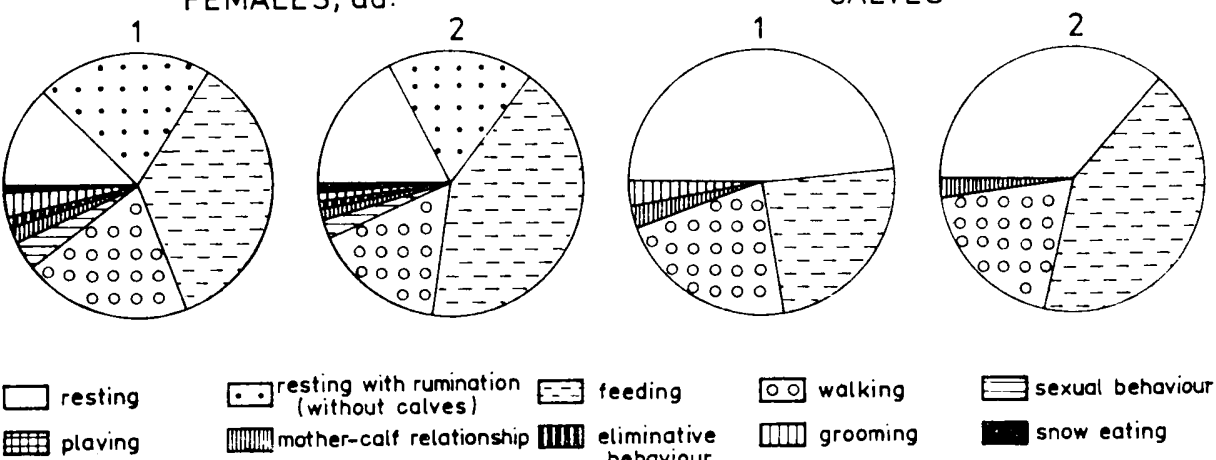

feeding

o0 walking

ploving

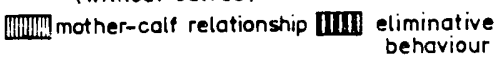

WDI grooming

sexual behoviour

snow eating

Fig. 1. Percentage of different types of daytime activity of European bison depedning on the animals' sex and age and on way in which hay is supplied. 1 - during period when hay is stored in stacks: 2 - during period when hay is laid out in small portions on the snow daily.

a similar percentage of the daytime as feeding. Rumination takes females and juveniles about $20 \%$ of the daytime, but only $10 \%$ in the case of bulls (Fig. 1).

Movement occupies European bison from 14 or $23 \%$ of daytime, young heifers being the most active, and bulls the least (Fig. 1). Since a certain number (although varying) of adult and sexually mature bulls enter the winter mixed group every year, sexual behaviour is observed in the herd, which occupies $14-29 \%$ of the bulls' daytime period, and lasts significantly longer in adult bulls $(0.02<P<0.05)$ than in young 
ones. Adult bulls spend more of the daytime in sexual behaviour if hay is not readily accessible (is not laid out on the ground), and this difference is statistically significant $(0.005<P<0.01)$.

All the animals were observed to eat snow, the young animals spending the longest time on this $(3 \%)$. Playing observed in juveniles and calves formed only a small percentage of their activity in winter $(2 \%)$. Grooming was observed in all groups of European bison and occupied $1-5 \%$ of their daytime activity (Fig. 1).

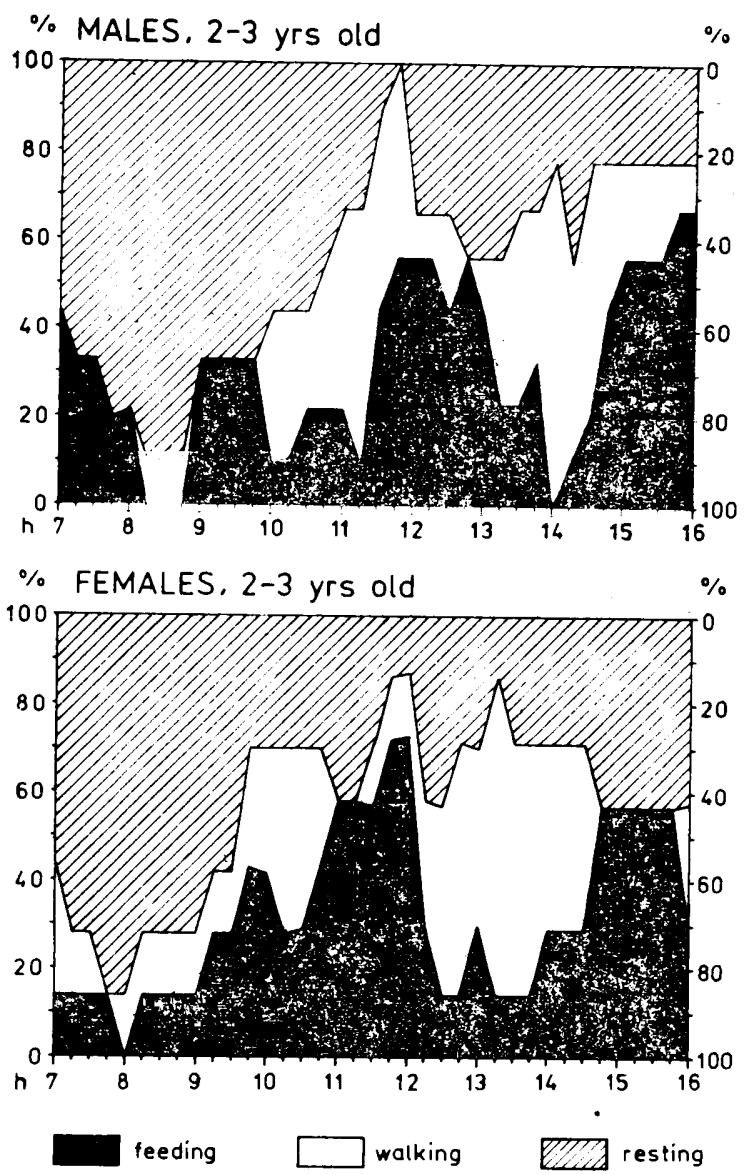

Fig. 2. Daytime activity rhythm of European bison in different age and sex classes, depending on the way in which hay is supplied.

A - hay stored in stacks; B - hay laid out in small portions.

When considering the frequency of a given activity during the day it can be seen that European bison feed 3-4 times, carry out grooming $1-3$ times, calves are fed $1-3$ times daily, while urination and defeca- 
tion was observed 1-2 times daily (Table 2). The feeding activity of different individuals is characterized by one period of long feeding $\left(1.30^{\prime}\right.$ to $\left.3.50^{\prime}\right)$ and several short periods lasting from 5 to thirty minutes. Maximum time of a single feeding period is twice longer in calves and adult bulls when hay is laid out than when it is stacked. No synchronization of feeding was observed in the daytime activity rhythm of different individuals in any of the age and sex groups, although

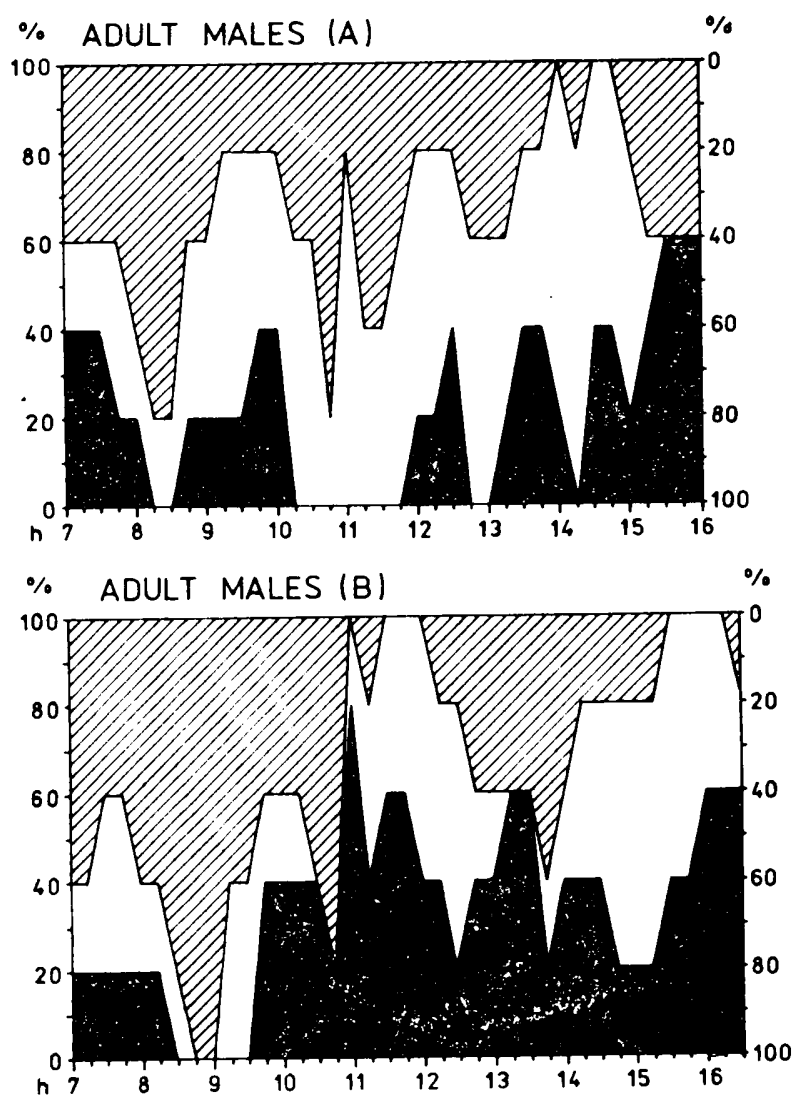

Fig. 2. Continued.

synchronization was observed in walking in the afternoon hours and resting in the early morning hours.

The behaviour of juvenile animals is characterized by several feeding peaks over the course of the day and a distinct resting phase during the early morning' (Fig. 2). The walking activity of these animals increases at noon and during the afternoon hours. Feeding by bulls has many phases like walking, which includes sexual activity and 
walking to the drinking place. The feeding activity of adult cows exhibits several peaks during the day. The largest number of cows $(60 \%)$ feed between the hours of 10.00 and 12.00 , during the time when hay is brought to the feeding place. The movement activity of calves is greater throughout the day when hay is stacked, due to the difficulty of their access to hay and their frequent attempts to get to it (Fig. 2).

Analysis of the daytime activity rhythm of these same individuals

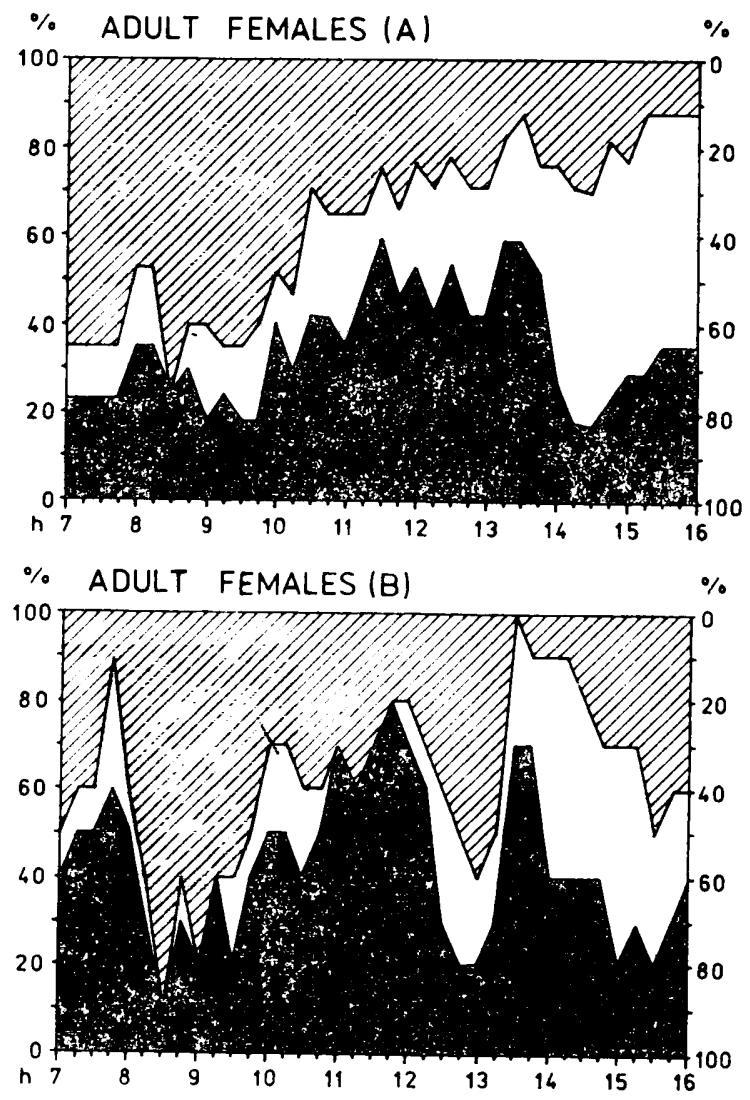

Fig. 2. Continued.

observed many times shows that there is no invariable individual rhythm (Fig. 3).

Examination was made of the effect of temperature on the course taken by activity phases in European bison. It may be said that the majority of European bison begin feeding in the early morning, when the temperature is about $0^{\circ} \mathrm{C}$, but with a severe frost $\left(-10^{\circ}\right.$ to $-19^{\circ} \mathrm{C}$ ) the majority of the animals rest in the morning (Fig. 4). The same animal feeds for longer during the day when there is frost than 
when temperature is above freezing (e.g. "Babula « at $+5^{\circ} \mathrm{C}$ fed for 2.7 hours, and with $-8^{\circ} \mathrm{C} 3.6$ hours, and "Pocieszna « at $+2{ }^{\circ} \mathrm{C}$ for 2.7 hours, but at $-17^{\circ} \mathrm{C}$ for 4.4 hours) (Fig. 3).

\subsection{Daily Activity}

European bison in the mixed winter group spent the greater part of the 24 hours $(60 \%)$ resting, feeding occupied them $30 \%$, and movement $10 \%$ of the 24 hours (Fig. 5). During the 24-hour period three peaks

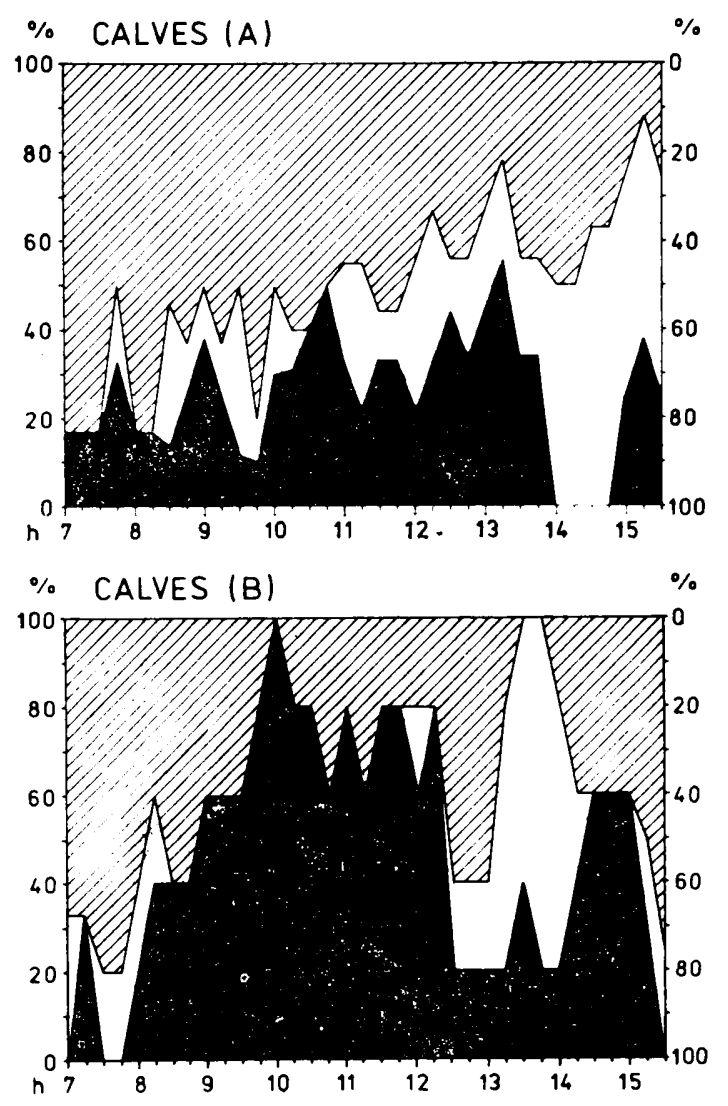

Fig. 2. Continued.

of feeding were observed (two during the daytime and a third before midnight). Feeding is an activity very little synchronized. Even during the period when the majority of the herd rests at night single individuals feed (Fig. 6). Two phases of rest can be distinguished, the majority of the group resting between 18.00 and 21.00 , then $80 \%$ of the herd rests again as from midnight to the early morning hours. Lying and standing, and particularly walking, are very well synchronized. 
In winter European bison exhibits very little moving activity over the whole 24-hour period, this only increasing between 13.00 and 15.00 when the animals move to the drinking place. Such movements take place once daily, and it is an activity which is very regularly repeated both on days with temperature above freezing and when there is severe irost. It begins between $12.00-13.00(36 \%$ of observations) or about $14.00(64 \%$ of observations) and lasts on an average 1.35 hours $(0.4-2.2$ hours) (Table 2).

The daily activity rhythm of the herd of European bison exhibits certain differences, in addition to considerable similarities, during the winter months. During the coldest month, February, the whole herd

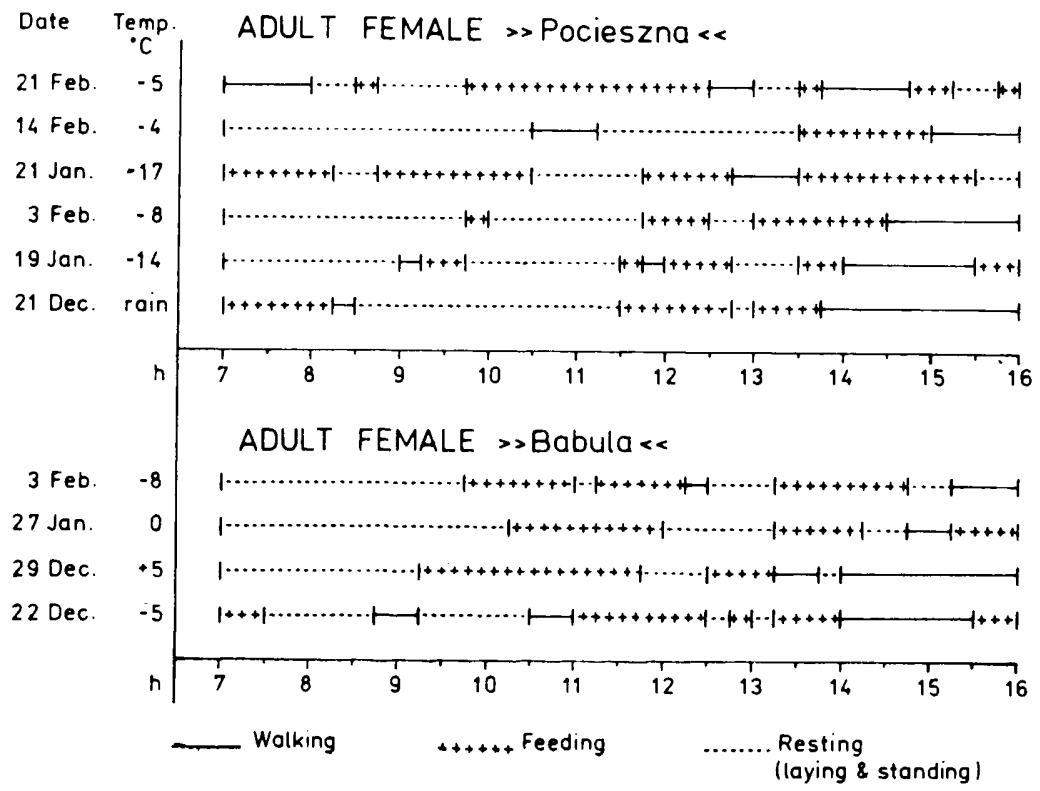

Fig. 3. An example of individual activity rhythm of two old cows.

rests until 11.00 a.m., and in the remaining months from $60-80^{\mathrm{o}} \%$ of the herd at this time (Fig. 7). During warmer winter months (December, March) the highest percentage of individuals are active over the course of the day. The course taken by feeding activity during the day differs from that observed in other months in February only, when morning feeding began late $(10.00)$, while from $10-40 \%$ of the herd fed as from dawn in the remaining months (Fig. 7). Extreme temperatures cause changes in the herd's activity in each month - for instance with temperature above freezing (thaw) many $(50 \%)$ of the bison feed as from dawn, while with a temperature of $-17^{\circ} \mathrm{C}$ the herd does not begin such activity until 08.30 , and the peak feeding period 

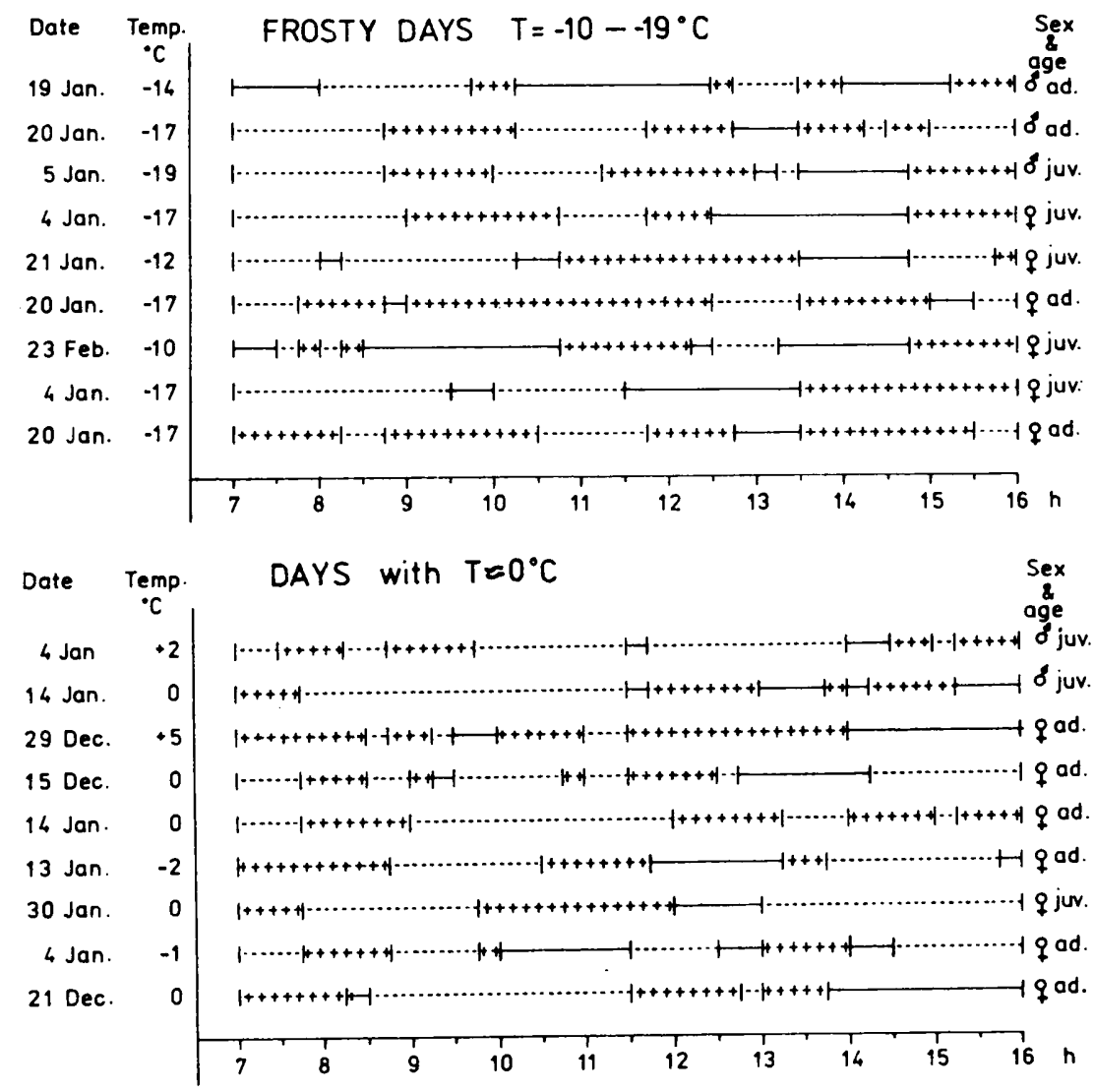

Fig. 4. Relation between individual activity rhythm and ambient temperature. Symbols as for Fig. 3.

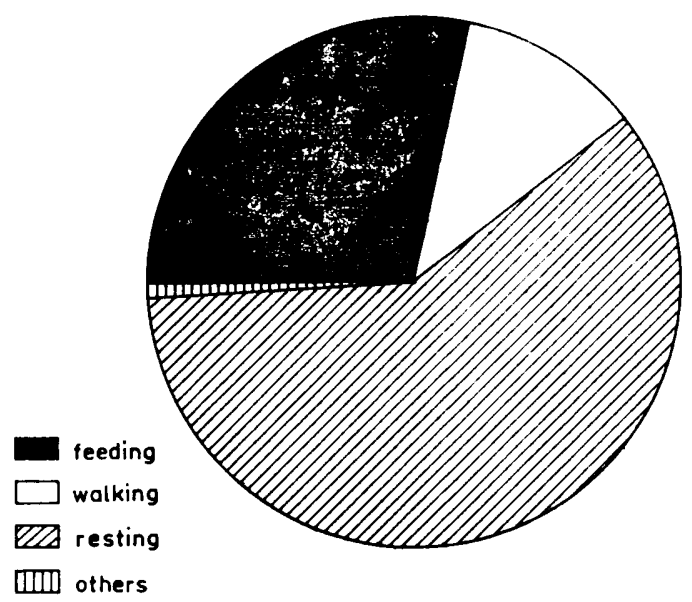

Fig. 5. Daily activity of the European bison herd, in $\%$, 


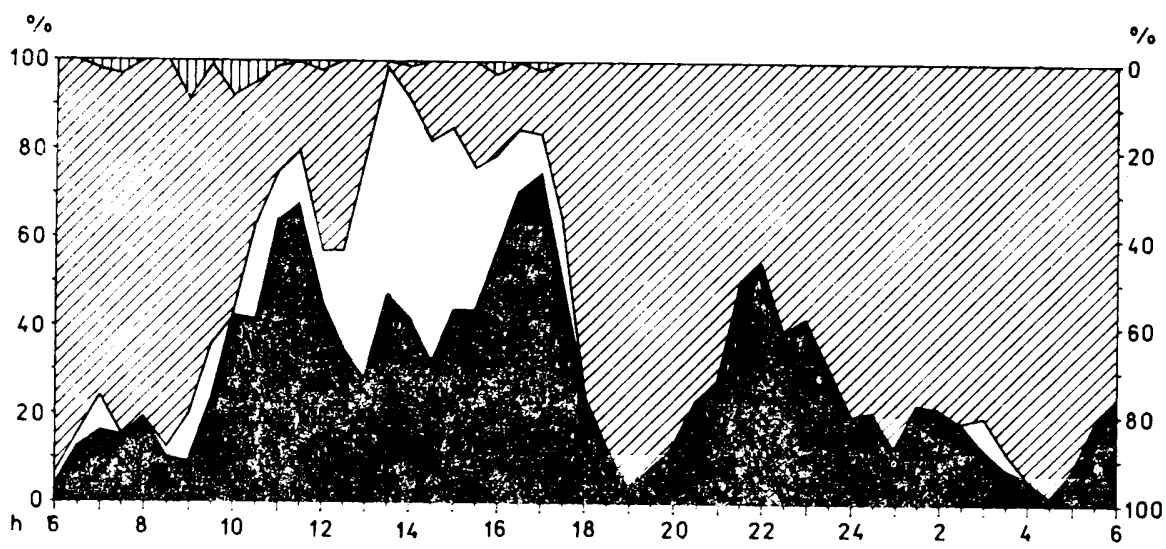

Fig. 6. 24-hour activity rhythm in the European bison herd.

Hatching as in Fig. 5, p. 290

was reached during the warmest part of the day before noon (Fig. 8). With severe frost the whole herd remains lying down between dawn and 09.00. During frost an additional phase of movement is also observed between 09.00 and 10.00 , which did not occur when there was a thaw (Fig. 8).
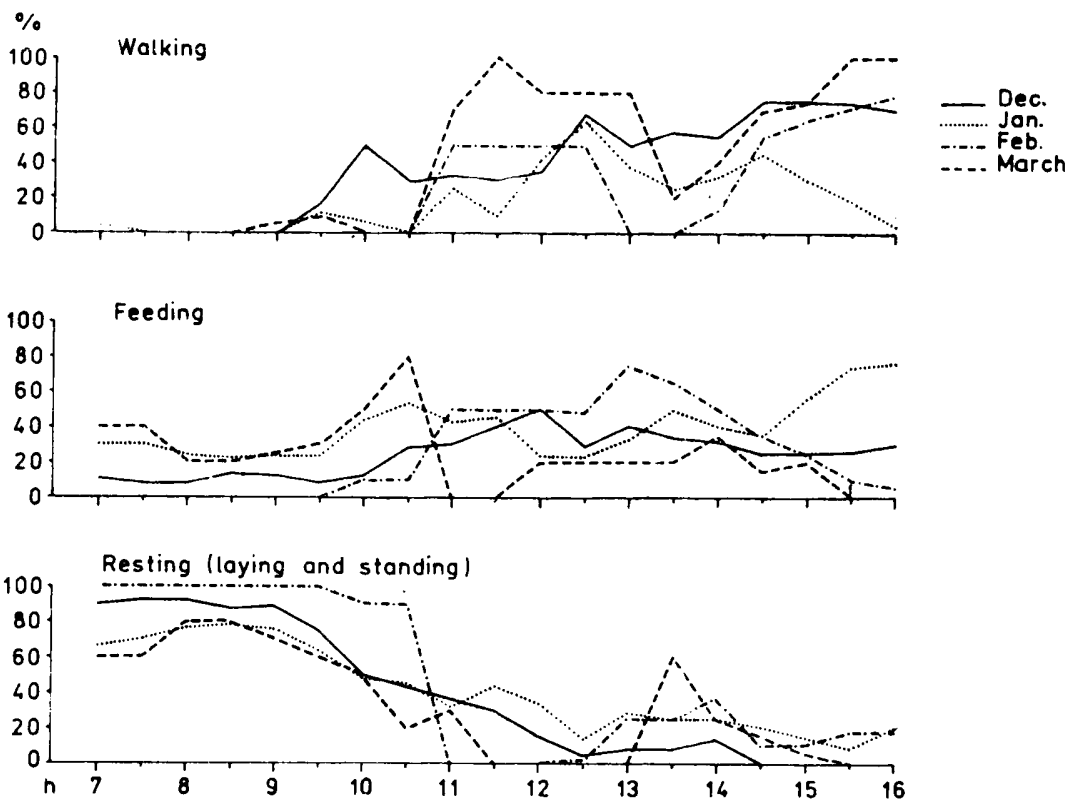

Fig. 7, Daytime activity of a European bison herd in different winter months, 


\section{DISCUSSION}

When analyzing feeding, grooming, and sexual behaviour, playing and cow-calf relationships of the European bison currently living in the Białowieża Primeval Forest, a great degree of similarity can be observed to the descriptions of their behaviour in animals from the last natural population living in the Forest during the 19th century (Karcov, 1903; Wróblewski, 1927). This shows that the long period of breeding European bison in zoological gardens has not changed the genetically established pattern of their behaviour. Today, as it was in the 19th century herd
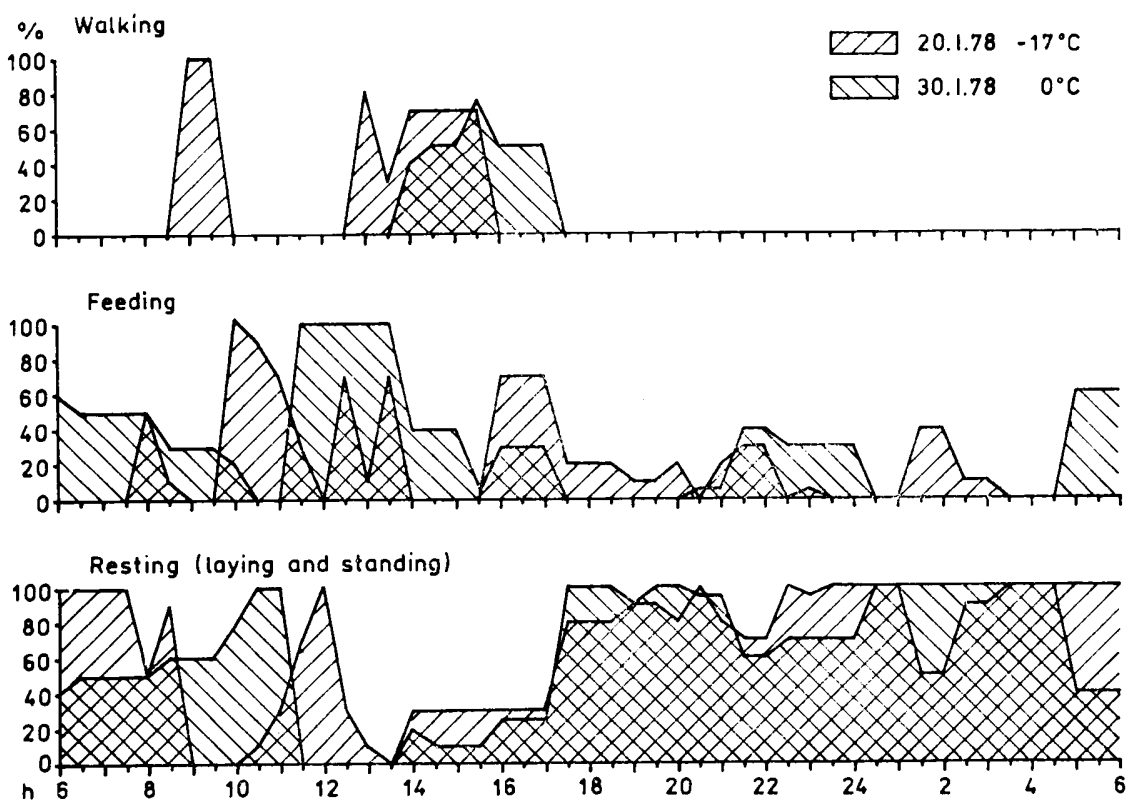

Fig. 8. 24-hour activity of a European bison herd during extreme temperatures $\%$ - percentage of the herd exhibiting the given activity $=\%$ of time spent in different activities in each quarter- or half-hour.

of European bison, they only irregularly make use of salt blocks, as is the case with the American bison (McHugh, 1958). There have been earlier reports of the fact that they drink water during winter and also eat snow (Karcov, 1903; Kulagin, 1919) and our studies provided confirmation of this. Like European bison, American bison also eat snow and break the ice on puddles to get at water (McHugh, 1958). In respect of grooming, agonistic, playing, eliminative and sexual behaviour there is considerable similarity to the characteristics of the behaviour of the 
American bison given by McHugh (1958), Herring \& Haugen (1970), Shult (1972). Cow-calf relationships of the two representatives of genus Bison are identical. During sucking calves of both European and American bison exhibit "heading off" behaviour. American bison calves suck from a few seconds to 21 minutes (Shult, 1972), and those of the European bison in winter from 3 to $26.5 \mathrm{~min}$ (Table 3). Juvenile individuals over one year old were several times observed to suck, or for two calves to be suckled by one cow, as was the case in the American bison herd at Wind Cave National Park (Shult, 1972).

The question of late calving and its consequences during the winter requires more detailed discussion. Krasiński \& Raczyński (1967) drew attention to the fact that this phenomenon led to sterility the following season and in consequence to a smaller increase in the numbers of the herd. The most favourable period for calving in the European bison is May-July, although some of the cows produce young in AugustOctober also. Calves born late grow more slowly and are the first to be attacked by invasive diseases, which in several cases were the cause of deaths (Krasinski, in prep.). Some cows repeat the oestrus several times, but when in calf late are unable to provide proper care for their calves during the winter concentration of the herd and exhibit lactation disturbance. As there is no natural selection in the free-ranging herd in the Białowieża Primeval Forest, artificial selection by man both of cows exhibiting deviation from the normal seasonal character of reproduction and late-born calves in poor condition, is beneficial (cf. álso Krasiński \& Raczyński, 1969).

The majority of wild ungulates are animals with many phases of daily activity rhythm, in which feeding periods are interspersed with resting phases. Generally speaking longer resting periods are observed at night, but there are some animals with decidedly daytime activity such as Rupicapra rupicapra (Linnaeus, 1758) (Briedermann, 1967). Feeding at night has been observed in many species of African antelope (Mitchell, 1977), roe deer (Hoffmeister, 1979) and American bison (Herring \& Haugen, 1970; Shult, 1972). The winter period, when ungulates often search for food under a deep snow cover, causes increased activity connected with satisfying their hunger. At the same time consumption of samewhat indigestible food, with abundant fibre, prolongs rumination time. Observations of this kind have been made in the case of reindeer, in which a significantly longer time of activity connected with obtaining food was observed in winter, and also longer rumination time than during summer (Gaare et al., 1975).

There are many phases in the daily activity rhythm of European bison, and feeding phases are interspersed with resting phases (cf. also 
Koročkina, 1972). European bison kept in enclosures exhibit similar rhythm (Van Den Brink, 1980). As there is no detailed information available on the activity of European bison living under natural conditions, the results obtained were compared with the observations made in summer of European bison kept in small enclosures in Prague Zoo (Vajner, 1980) and the Amsterdamse Bos reserve (Van De Brink, 1980). Comparison shows that the pattern of activity is specific, but that distribution of activity phases in time is modified by the season of the year and feeding system.

In the Białowieża herd of European bison two peaks of feeding were observed during the day in winter (Fig. 6). Single individuals may rest during a feeding peak or some might feed during a rest phase. Such facts were recorded in winter in the Białowieża Primeval Forest and in summer in enclosures (Van Der Brink, 1980). In winter in the case of the Białowieża herd the third peak of feeding occurs during the hours of night between 21.00-24.00. In summer European bison in Prague Zoo (Vajner, 1980) and American bison also fed during the middle of the night (Herring \& Haugen, 1970; Shult, 1972).

Supplementary winter feeding of European bison results in reduced locomotor activity of the animals (our data and those given by Koročkina, 1972). Individuals in the mixed winter group live in the immediate vicinity of feeding places and do not move further away from them than $250-300 \mathrm{~m}$. It is only adult bulls which often move to other feeding places situated at distances of up to $5 \mathrm{~km}$. Increased activity was caused among the animals by hay being brought to the feeding places, and in particular this applied to beet, and by their voluntary move to the drinking place. From December-March European bison supplement their diet to a small degree with natural food in the form of tree bark and shoots. Supplementary winter feeding with hay in the Białowieża Primeval Forest satisfies their food requirements and in this way limits the damage in tree stands to those in the vicinity of the feeding places. Interest in natural food increases at the end of March/beginning of April, depending on the time the snow cover disappears.

In winter when European bison are supplied with food it was not possible to obtain detalied data on domination and hierarchy in the herd. In summer, when groups are small (the majority of them consists of up to 20 individuals, Krasiński, 1978) the herd is always led by an adult cow, and even when a bull is present in the group during oestrus it does not take over leadership from the cow. The domination of a bull in the herd at Prague Zoo described by Vajner (1980) is only encountered in artificially formed groups in an enclosure, and has also 
been observed at Białowieża. This domination pattern cannot be applied to a free-ranging herd.

The combined amount of time spent by European bison in feeding does not depend on the season of the year. In winter Białowieża bison spend a similar amount of time in feeding during a 24-hour period as they do in summer in Prague Zoo (Vajner, 1980). Animals feeding solely on natural food, such as e.g. reindeer (Gaare et al., 1975) spend a far longer time feeding in winter than in summer. In winter European bison ruminate for $10-22 \%$ of the daytime hours, but in summer in the zoo they spent a far greater part of the 24-hour period, i.e. $40 \%$ in ruminating. The time spent in playing, resting and grooming was similar under both conditions.

When examining the daily activity rhythm in a large winter group of about 60 individuals, no full synchronization in time was found in the behaviour of different individuals. In large enclosures also in summer a group of 6 European bison failed to exhibit ideal agreement in the activity rhythm of individuals, and it was only in the early morning that all bison were feeding at the same time (Van Den Brink, 1980). In a group of 9 European bison in Prague Zoo the animals exhibited complete coincidence in the activity rhythm of different individuals (Vajner, 1980). It may be concluded from this that under natural and semi-natural breeding conditions the individual rhythm of a given animal is manifested in certain forms of activity, not always coinciding with the activity of the whole herd. This is not observed in the completely artificial conditions of zoological gardens, where activity rhythm is to a great degree imposed by man.

Imitation greatly influences the occurrence of some forms of activity in herds of ungulates. These are species in which the whole of daytime activity is well synchronized, such as in the gerenuk and giraffe (Leuthold \& Leuthold, 1978). The reindeer exhibits a high degree of synchronization of feeding and lying, which may result in the whole herd changing from movement or feeding to lying down within $15 \mathrm{mi}$ nutes (Gaare et al., 1975). Feeding in Oreotragus oreotragus (Tilson, 1980 ) is less well synchronized, but resting is synchronized in a similar way to that of the lesser kudu (Mitchell, 1977). Thomson's gazelle exhibits considerable synchronization of both feeding and lying within 15-30 minutes after ceasing movement the whole group lies down (Fisher, 1966 cited after Shult, 1972). The Białowieża bison in winter has most highly synchronized resting (lying) and walking to the drinking place. The animals can be seen in turn to lie down and gradually $80-90 \%$ of the herd is recumbent (Fig. 6). Similarly within 30 minutes $80 \%$ of the herd is walking to the drinking place. The fact 
that a certain number of bison is always feeding during the 24-hours period is due to the easy access to hay. Animals which had previously been driven off eat when the other animals rest.

To sum up it may be said that winter supplementary feeding carried out in the Białowieża Primeval Forest limits the locomotor activity required under natural conditions to search for food, which is favourable to the organism as it limits deterioration in condition, but simultaneously reduces synchronization of the activity of different individuals connected with food consumption, as a result of the constant presence of easily accessible food. The genetically imprinted basic pattern of behaviour in European bison is exhibited undisturbed in winter.

Certain practical conclusions arise from observations of the behaviour of European bison in winter, and these may be useful in managing tree-ranging breeding. It is essential to continue selection of late-born calves in poor condition, and of cows repeating the oestrus and calving late, which usually take little care of their calves. Proper supplementary feeding should ensure that all the animals have access to hay. This is of great importance to proper condition of calves, which spend twice as much time on eating hay when it is laid out in numerous portions on the snow. The daily laying-out of hay on snow at present in practice in the Białowieża Primeval Forest is only a half-measure, laborious and expensive, and attended by considerable waste of fodder. It would be useful in the future to build a large number of small feeding places, sufficiently numerous for all bison to have simultaneous access to the food. When planning building of feeding places for European bison it is also necessary to distribute small feeding places for bulls at a certain distance, as they only periodically live in mixed groups. As it has been found that European bison regularly drink water in winter it is essential to build such feeding places on suitable sites.

\section{REFERENCES}

1. Briedermann L., 1967: Zum Ablauf der sommerlichen Aktivitätsperiodik des Gamswildes (Rupicapra r. rupicapra (L. 1758)) in freier Wildbahn. Zool. Garten, 33: 279-305.

2. Brink Van den W. J., 1980: The behaviour of wisent and bison in larger enclosures. Acta theriol., 25: 115-130.

3. Gaare E., Thomson B. R. \& Kjos-Hanssen O., 1975: Reindeer activity on Hardangervidde. [In: "Fennoscandian tundra ecosystems", 2: 206-215. Ecological studies. Analysis and synthesis. Wielgolaski (Ed.)]. Springer Verlag. Berlin, Heidelberg, New York.

4. Herring D. M. \& Hagen A. O., 1170: Bull bison behavior traits. Proc. Iowa Acad. Sci., 76: 246-262. 
5. Hoffmeister H., 1979: Untersuchungen über die Reaktion von Reh- und Damwild auf verschiedene Umwelteinflüsse unter Einsatz der telemetrischen Erfassung von Herzfrequenz und EKG. Dr Med. Vet Thesis: 1-84. Institut für Wildtierforschung. Hannover.

6. Karcov G., 1903: Belovežskaja Pušča. Artist. Zaved. A. F. Marksa: 1-414. S. Petersburg.

7. Klingel H., 1967: Soziale Organization und Verhalten freilebendes Steppenzebra. Z. Tierpsychol., 24: 580-624.

8. Koročkina L. N., 1972: Sutočnyj ritm aktivnosti zubrov Belovežkoj Pušči. Belovežskaja Pušča, 6: 125-131.

9. Krasiński Z. A., 1967: Free living European bison. Acta theriol., 12: 391-405.

10. Krasinski Z. A., 1978: Dynamics and structure of the European bison population in the iBałowieża Primeval Forest. Acta theriol., 23: 3-48.

11. Krasiński Z. A. \& Raczyński J., 1967: The reproduction biology of the European bison living in reserves and freedom. Acta theriol., 12: 407-444.

12. Krasiński Z. A. \& Raczyński J., 1969: Z badań nad rozmnażaniem się żubra w polskich rezerwatach hodowlanych i na wolności w Puszczy Białowieskiej. Postępy restytucji żubra, 2: 205-232.

13. Kulagin N. M., 1919: Zubry Belovežskoj Pušč. Izd. Mosk. Naučn. Inst: 1-166 Moskva.

14. Leuthold B. M. \& Leuthold W., 1978: Daytime activity patterns of generuk and giraffe in Tsavo National Park, Kenya. E. Afr. Wildl. J., 16: 231-243.

15. McHugh T. S., 1958: Social behaviour of the American buffalo (Bison bison bison). Zoologica, 43: 1-40.

16. Mitchell A. W., 1977: Preliminary observations on the daytime activity patterns of lesser kudu in Tsavo National Park, Kenya. E. Afr. Wildl., 15: 199-206.

17. Pucek Z., 1976: The most imporiant problems for further studies on European bison. Acta theriol., 12: 495-501.

18. Shult M. J., 1972: American bison behavior patterns at Wind Cave National Park. Iowa State University, Ph. D. theses, Zool.: 1-178.

19. Tilson R., 1980: Klipspringer (Oreotragus oreotragus) social structure and predator avoidance in a desert canyon. Madoqua, 2: 303-313.

20. Walther F. R., 1973: Round-the-clock activity of Thomson's gazelle (Gazella thomsoni Günther, 1884) in the Serengeti National Park. Z. Tierpsychol., 32: $75-105$.

21. Vajner L., 1980: Etologická studie stáda zubrů evropských, Bison bonasus Linnaeus, 1758) v pražské ZOO. Gazella, 2: 59-69.

22. Wróblewski K., 1927: Zubr Puszczy Białowieskiej. Wyd. Polskie: 1-232. Poznań.

Accepted, February 28, 1983. 
Krystyna CABOŃ-RACZYŃSKA, Małgorzata KRASIÑSKA, Zbigniew A. KRASIŃSKI

\section{BEHAWIOR ORAZ RYTM DOBOWEJ AKTYWNOSCI ŻUBRÓW W ZIMIE}

\section{Streszczenie}

Badania nad zachowaniem się i rytmem aktywności żubrów, pochodzących z ugrupowania mieszanego wolnożyjącej populacji żubrów w Puszczy Bialowieskiej prowadzone od grudnia do marca w latach 1976-1981. Ugrupowanie to liczylo 55-60 osobników. Rytm dobowej aktywności określano dla podstawowych typów zachowania jak: żerowanie, ruch odpoczynek (leżenie i stanie). W fazie aktywności ruchowej wyróżniano ruch wlaściwy, zachowanie zabawowe, seksualne i kosmetykę.

Rytm dziennej aktywności żubrów badano metodą bezpośrednich obserwacji ciągłych, od świtu do zmroku. Aktywność dobową badano podczas pełni księżyca. Behawior żubrów określano prowadząc $2-3$ godzinne obserwacje w różnych porach dnia, a także podczas badań aktywności dziennej. Łącznie przeprowadzono 635 obserwacji behawioru żubrów podczas zimy. Przeprowadzono 94 obserwacje aktywności, w tym 9 obserwacji dobowej aktywności stada, 17 dziennnej aktywności stada i 68 obserwacji poszczególnych osobników w różnym wieku.

Rytm aktywności dobowej żubrów jest wielofazowy, fazy żerowania sa przeplatane odpoczynkiem, podczas którego zwierzęta przeżuwają zjedzony pokarm. W ciągu doby obserwujemy 3 fazy żerowania (dwie $w$ dzień i trzecią przed północą). Stado żubrów przeznacza 60\% czasu na odpoczynek, żerowanie zajmuje im $30 \%$ czasu, ruch $10 \%$ (Ryc. 5,6 ). W odpoczynku wyróżniamy 3 fazy, większość stada odpoczywa między 18-21 i od północy do wczesnych godzin rannych. Zimą ruchliwość żubrów jest niska na co duży wpływ ma obecność latwo dostępnego pokarmu. Wzrasta ona jedynie między 13-15 godziną kiedy większość stada wędruje do wodopoju w olsie oddalonym o $200-250 \mathrm{~m}$ od paśników.

Duży wpływ na czas żerowania w ciągu dnia wywiera sposób podawania siana żubrom. Czas żerowania jest istotnie dłuższy $u$ dorosłych samic i samców, a $u$ cicląt nawet dwukrotnie dluższy, gdy siano jest rozkładane $w$ małych porcjach na dużej przestrzeni, niż gdy dostępne jest tylko w brogach (Tabela 1, 2; Ryc. 1. 2). Przeżuwanie zajmuje samicom i młodzieży $20 \%$ czasu dnia, a samcom tylko $10 \%$. Największą aktywność ruchową wykazują młode jałówki i cielęta (Ryc. 2).

Naśladownictwo ma wplyw na wystąpienie niektórych form zachowania żubrów $w$ dużym ugrupowaniu zimowym, szczególnie dotyczy to leżenia (odpoczynek) 1 wędrówki do wodopoju. Konsumpcja siana nie jest wysoko zsynchronizowana w czasie. Nie stwierdzono również pełnej zgodności w czasie faz dziennej aktywności osobników, z różnych grup wiekowo płciowych (Ryc. 2).

Większość cieląt znajdujących się w zimowym ugrupowaniu pochodzi z wczesnych urodzeń (maj-lipiec), zdarzają się jednak również cielęta późno urodzone (sierpień-październik). Czas karmienia cieląt podczas zimy z grupy pierwszej jest średnio dłuższy i wynosi $8.3(3.3-24)$ minuty niż drugiej 6.3 (3-26.5) min Tabela 3.

W dyskusji porównano uzyskane wyniki $\mathrm{z}$ danymi o zachowaniu się żubrów z ostatniej naturalnej populacji, żyjącej w Puszczy w XIX wieku i stwierdzono, że wieloletni chów $w$ ogrodach zoolgoicznych i rezerwatach nie zmienil utrwalo- 
nego genetycznie wzorca zachowania. Równocześnie stwierdzono duże podobieństwo w zachowaniu żubrów i bizonów.

Przeprowadzone badania pozwalają stwierdzić, że przez całą zimę żubry z wielkich ugrupowań mieszanych przebywają $w$ najbliższym sąsiedztwie miejsc dokarmiania. Dokarmianie niemal $w$ pelni pokrywa ich dobowe zapotrzebowanie ookarmowe i jednocześnie ogranicza szkody $w$ drzewostanach do najbliższych okolic paśników.

Można też wyciągnąć praktyczne wnioski dla zarządzania wolną hodowlą żubrów: (1) Celowe kontynuowanie jest co roku selekcji żubrzyc rodzących cielęta poza właściwym terminem rozrodu oraz cieląt pochodzących $\mathrm{z}$ późnych wycieleń, a będących w slabej kondycji. (2) Siano przeznaczone na zimowe dokarmianie powinno być składowane $\mathrm{w}$ małych paśnikach, których liczba powinna zapewnić jednakowy dostęp do paszy wszystkim osobnikom. (3) Planując nowe miejsca dokarmiania w okresie zimowym należy brać pod uwagę konieczność korzystania przez żubry z wody. 